\title{
Reading Imaginative Futures across Historical Moments; Or Speaking Surreptitiously in Imperial Centres
}

\section{Shiera S. el-Malik*}

\begin{abstract}
Léopold Sédar Senghor's 1961 Speech at Oxford University is a provocative and critical intervention during what is generally considered to be a decolonisation period. It is a speech that engages across eras, and one from which we can glean insights on how to nourish ideas and modes of thinking that may be needed in this historical moment. With it, Senghor illustrates the importance of humanism for interlocutory dialogue, which is necessary to transcend delimiting and violent kinds of relations. This article deploys the idea of surreptitious speech to examine how Senghor makes these arguments in a crevice moment. I present a homologous reading of Senghor's speech using the lecture itself as a base with its three sections: 'Negritude as a Form of Humanism,' 'The African Mode of Socialism', and 'Conclusion'. Atop the speech, this essay develops in five sections that mirror the re-imagining and the future imagining that Senghor accomplishes with his words. I suggest that this speech represents a vision of a humanistic, decolonial future that keeps alive the idea and the hope of a more universal universalism.
\end{abstract}

Keywords: Negritude; Humanism; Imagination; Dialogue; Experience; Culture; Dehumanisation.

[T] he first condition of dialogue... is the existence of interlocutors who recognize each other as such, who pay attention to each other (Diagne 2011: 145).

\section{Introduction}

The president of Senegal, Léopold Sédar Senghor, begins a Speech at Oxford University in 1961 by thanking his hosts and presenting himself as a professional insider. He opens with, 'I must first tell you how deeply this reception by the University of Oxford has touched me as a Teacher...' (Senghor 1961:2, emphasis in original). Constituting a shared space of parity between himself and his audience with these words, he adds 'This is not the first time I have been here; I even stayed here once, at St. Anthony's College, not as a student of course, but as a visiting lecturer' (Senghor 1961: 2, emphasis my own). And, he locates the mean-

* DePaul University, Chicago-IL, United States; shiera.malik@depaul.edu. 
ingfulness of the meeting place: 'the ancient University, whose very name sets the hearts of countless men and women, all over the world, beating with emotion' (Senghor 1961: 2). Our speaker interpellates his 1961 audience (and everyone thereafter) as interlocutors with these prefatory comments made at the start of a speech at an ancient and imperial centre of learning and knowledge production. The speech itself traverses the mid-twentieth century, and Cold War geo-politics of (post-, de) colonial relations at this historically important site and starts with the understanding that 'the first condition of dialogue, that which makes it even possible, is the existence of interlocutors who recognize each other as such, who pay attention to each other [recognizing that w] hat colonial situations by definition forbid is precisely this situation of interlocution' (Diagne 2011: 145).

Léopold Senghor (1906-2001) was a statesman with a reputation for being a skilled speaker who engaged the expectations of his audience before launching his challenge. ${ }^{1}$ Oratory skill aside, the meticulousness of his claims reflects a deeply critical and transcendent engagement with a politics of a specific historical moment, although he is only rarely read in this way. More often, Senghor is read as a statesman who, interested in aesthetics, sacrificed the idea of decolonial independence by arguing instead for a French Federation (Wilder 2015). My reading highlights a poet-scholar-statesman for whom the fundamental problem of colonialism is dehumanisation, and who consequently imagines that for decolonisation to occur, humanisation must also take place. My reading observes Senghor nimbly package this relatively simple argument in a speech at a time when decolonisation was becoming synonymous with self-determination and national independence. I see Senghor as having saved for future imaginaries this argument regarding the necessity of recognising peoples' humanity. This seems a good time to take down his parcel, consider the tools he has gifted us from another time, and reinvigorate the notion that people matter in the study of politics.

With related aims, I think, Mudimbe (1992) uses the idea of 'surreptitious speech' to describe the way that the intellectual group, journal, and publishing house Présence Africaine both reflected and created a space for voices, ideas, and modes of communication that developed out of critiques of colonialism. In his view, Présence Africaine cultivated a surreptitiousness, which as I understand it can emerge as a strategy out of particular relational dynamics in which the relatively 'weak' use their proximity to the relatively 'strong' to launch challenges (to colonialism, for example). But, what seems more surreptitious to me is that it was not simply a strategy of the weak. It was also a space in which scholars of power and politics of the mid-twentieth century practiced, honed, and articulated their critique, unthinkable as it may have seemed. ${ }^{2}$ Mudimbe writes of the space Présence Africaine cultivated that ' $[i t]$ is not the other side of what we may call the Western space. In fact, it belongs to it...' (Mudimbe 1992: 435). Thus, the notion of what we might call 'Western space' (constituted from colonial power dynamics) is in fact the condition of possibility for the emergence of Présence Africaine as another space for engaging dynamics of coloniality in its variations.

However, I am less interested here in thinking about Présence Africaine (although Senghor's involvement extends its relevance) than I am in thinking about how surreptitiousness might work to nourish and protect storylines that imagine futures. If historical 
narratives can incorporate storylines that are - or are made to be - generally unintelligible to those at the time of their emergence, as was Présence Africaine, then I wonder where those storylines live. What happens to the futures that were imagined in those spaces, but did not come to be? I am positing that the intelligibility of political imaginaries depends on interlocutory spaces; it depends on how those storylines are made to make sense in specific moments, on how they remain available for engagement. With this in mind, I can take up Senghor's offering of a way to conceptualise and argue against coloniality and its dehumanising practices, at a time when I am growing heavy with the shared grief of watching bodies pile up.

My emphasis rests on how we as scholars of coloniality in its various guises engage these offerings. 'Thinking with' the stories of these other storytellers,

[I]s not just an exercise in contextualization; it also means listening carefully to what their analysis of that world might teach us about ours, treating them not only as native informants symptomatic of their era but as critical thinkers whose formulations about politics, aesthetics, and epistemology might help us fashion frameworks with which to reflect upon related phenomena (Wilder 2015: 12).

The idea of surreptitious speech encourages us to engage thinkers as critical analysts of their particular moment, which can teach us much about how to be critical analysts of our particular moment. But, reading across historical moments requires a kind of decentred grounding of the location of the self, a kind of reorienting of what we mean by the here and now. In this speech, for example, Senghor reflects on his student days in Paris some 20 or so years earlier when he and his colleagues developed the Negritude movement. He also reflects on his contemporaneous moment as President of Senegal in 1961. All the while, in this essay this 'I' is thinking and writing about Senghor's reflections of a 1930s Parisian moment, a 1960s moment that coalesces leadership, Oxford, and Senegal (by my current reading), and from Chicago in 2016, where amongst other observations, I notice that the permeating violence is increasingly altering my carriage, my gait, and my disposition. In what follows, I present a homologous reading of Senghor's speech using the lecture itself as a base with its three sections: 'Negritude as a Form of Humanism, 'The African Mode of Socialism', and 'Conclusion'. Atop the speech, this essay develops in five sections that mirror what Senghor accomplishes with his words. The sections are: 'Reimagining Human-ness', 'Reimagining Culture, 'Imagining a Universal Humanism,' 'Imagining a Humanistic Future', and 'Reading Imaginative Futures with Senghor'.

\section{Reimagining human-ness}

In his prefatory comments, Senghor proceeds to juxtapose the epistemological patterns that constitute British and French 'learning': Oxford University has 'made the greatest contribution to the growth of Western Civilization' (Senghor 1961: 2). He reminisces, 'I well remember how, during my years at the Sorbonne, I often had occasion to use Oxford editions of the great authors who were set for study' (Senghor 1961: 2). Senghor suggests 
that British scholarly work can be read as worldly - at least in comparison to French scholarly work because, '[it has] not confined [its] studies to Homo Europaeus, nor even to the white man, but [has] widened them to take in the whole planet, notably black Africa' (Senghor 1961: 2). Distinguishing Francophonic knowledge practices, Senghor points out, 'You in Britain have been criticized, in the past, for not having a sense of universality, for your refusal to assimilate native populations' (Senghor 1961: 2). He offers furtive praise for the British form of imperialism when he says that, 'Today, you are praised for having emphasized points of difference rather than of similarity' (Senghor 1961: 2). ${ }^{3}$ Senghor is highlighting a politically productive epistemic opening when he says that, 'The University of Oxford, through its chairs devoted to overseas studies, continues to teach the knowledge of these hidden springs of life' thereby recognizing other knowledges (Senghor 1961: 2). The introductory section of Senghor's speech connects Oxford's gravitas with its Commonwealth learning - both non-assimilationist and non-universalist. With these words at an imperial centre of learning, Senghor implicates both British and French versions of colonial (and racial) domination as inculcating an international crisis in the form of the decolonisation moment, although he contests what makes it a moment and how to think about decolonisation. The idea of other knowledges or multiple knowledges is significant, for it presents a discursive opening and one of which Senghor is poised to take advantage, although later we see him turn towards a universal universalism in which assimilation is not a unidirectional process.

Negritude as a Form of Humanism: In the first body section of the speech, Senghor disturbs the 'othering' of the students who developed Negritude by framing it as a spectacularly normal response of a group of young people. ${ }^{4}$ Senghor relates the story of a reporter who asks him about whether or not Negritude is a new form of humanism. In response, Senghor notes, 'I must admit that it was indeed, in its early days, "an anti-racial racialism", as Jean-Paul Sartre calls it in his Orphée Noir' (Senghor 1961: 2). ${ }^{5}$ But our orator situates Negritude in the conditions of its emergence, which include the body and lived experience. He depicts their - the students' - 'frustration and shame' at having achieved success academically, institutionally, and because of their impeccable French only to find themselves marked by DuBois' colour line (Markovitz 1969: 51; DuBois 1994). Calling attention to the youth, the intellect, and the naiveté of his cohort, Senghor asks his audience to imagine putting on a black skin. ${ }^{6}$ He says,

Now, try to put on a black skin for five minutes. I know you find this hard to do, but there is no other way to get the living feel of our situation. Go back in time some thirty years, to the years between the two World Wars. We black students in the Latin Quarter [of Paris] were filled with pride, passion, and also the naïve ignorance of youth (Senghor 1961: 2, 4).

We had been taught, by our French masters at the lycée, that we had no civilization, having been left off the list of guests at the Banquet of the Universal. We were 'tabula rasa', or, better still, a lump of soft wax 
which the fingers of the white demiurge would mould into shape. The only hope of salvation you could hold out to us was to let ourselves be assimilated (Senghor 1961: 4, emphasis in original).

The listeners are hailed with black skin in order that they inhabit a marked position, even for a moment, and so that they recognise the deeply insidious barriers to assimilation, as well as how those barriers worked in the service of colonial domination and governance. This surrealist strategy that refuses the cultivated distance between speaker and listeners might be understood as surreptitious insertions of other knowledge practices or modes of world-making. But, I think it simply allows Senghor to insist on the humanity of colonised people and to present a response to colonial dehumanisation (Negritude, in this case) as logically coherent and consistent in that moment, even if flawed and subject to rethinking. This is what I think makes it a surreptitious communiqué. Think of it: more than hailing the listener as a co-conspirator, Senghor's oration hails the listener as his interlocutor - as one who could imagine the sentimental [experience] of Negritude [as] the affirmation of self as a potential participant in a dialogue, a rightful subject in an interlocutory situation' (Diagne 2011: 146). With an interlocutor, the possibilities of deeper empathic engagement expand even if interlocutors are politically opposed. In this case, we could read into the context that Senghor is speaking at a university with few African students about a different education system in which cohorts of black students achieved scholarly excellence a generation before because his words imply a largely white audience or people who do not normally 'wear black skin'.

Within his discussion of Negritude's origins, Senghor foregrounds a lived experience in a different temporal moment from the one in which he is speaking. After all, he delivers this speech more than twenty years after the birth of Negritude. With hindsight, he acknowledges 'that this revelation [that intellect alone cannot comprehend all of human experience in the world] went to our heads, and set us well on the way to racialism' (Senghor 1961: 6). The students, in Paris, in the interwar years, far from their comfort zone, sought solace in that which offered them a positive view of what was to blame for their exclusion: their blackness. Senghor remembers, 'we were harshly uncompromising as neophytes and our attitude was reinforced by all the resentment stirred in us by the colonial regime. We refused to cooperate; we took pleasure in root and branch opposition to Western civilization' (Senghor 1961: 6). It is noteworthy that far from negating or apologising for their response to French assimilation, Senghor's rhetorical strategy insists on their ordinary humanity despite the dehumanising colonial context. ${ }^{7}$ His goal of dialogue requires this persistent claim to ordinary human desires, and to consistently locate African students in the system as producers of knowledge. As a site of elocution, Oxford affords the opportunity to re-narrate the complex dynamics of colonialism and colonial experience from a starting point that assumes the human-ness of the participants to whom the British imperialistic approach to difference offered an alternative discourse. Consider that,

In the University of Oxford this new science [of Ethnology] held a place of honour long before its triumphal entry into the Sorbonne. That is the first point I wished to make, and for which I wanted to 
praise You, the University of Oxford, who so promptly invited the black man take his seat at your Banquet.

...[W]hat matters is that the Black Man was present among you, and that you treated him like a brother, who might be the youngest member of the family, but had something worthwhile to say. What matters is that, through its most famous university, Great Britain recognized the Negro African personality, and considered it digna amari, worthy of fostering. A fact to which the United Kingdom had for a long time given expression through its policy of indirect government' (Senghor 1961: 4).

Senghor is suggesting that indirect government was an indicator of a recognition of Black Personality, although subordinate. But, more than a recognition of the virtues of British ethnography, which carried notions of European superiority, I read this as a dressing down of French ethnography. If 'the ethnographer... was directly engaged in defining the terms of the struggle for authority [at the time]' (Genova 2004: 98), then their siding with the French colonial administration against the students places British ethnography (although still colonial and hierarchical) in a positive relation with those trying to create spaces for dialogue. And, French ethnographers did play a key role in managing the threat posed by the educated Africans' challenge to the colonial status quo (Genova 2004: 99).

This political struggle presented productive paths for political engagement; Senghor and others used it to develop a platform for a kind of surreptitious engagement that originated from their very claims to be human, to be potential interlocutors. Consider the following:

[W] hat do you mean by Negritude you may ask, in company with the friendly journalist from the much-respected Times. To answer your question, may I again recall my student days in the Latin Quarter? Paradoxically, it was the French who first forced us to seek its essence, and who then showed us where it lay.

The French forced us to seek the essence of Negritude when they enforced their policy of assimilation and thus deepened our despair. It almost drove the West Indian poet, Aimé Césaire, who had become a Negro-African in spirit, to insanity. Early on, we had become aware within ourselves that assimilation was a failure; we could assimilate mathematics or the French language, but we could never strip off our black skins nor root out our black souls. And so we set out on a fervent quest for the Holy Grail: our Collective Soul. And we came upon it. It was not revealed to us by the 'official France' of the politicians who, out of self interest and political conviction defended the policy of assimilation. Its whereabouts was pointed out to us by that handful of free-lance thinkers - writers, artists, ethnologists, 
and prehistorians - who bring about cultural revolutions in France. It was, to be quite precise, our teachers of Ethnology who introduced us to the considerable body of work already achieved, in the understanding of Africa, by the University of Oxford (Senghor 1961: 4-6).

Senghor is clever in his depiction of the young students. What he avoids detailing is the extensive debate that spurred their response. 'By the early 1930s many évolués [saw] their task in the colonial field [as] to lead a "cultural renaissance" in West Africa' (Genova, 2004: 78). Senghor says, 'I ought at this point, you may think, to define Negritude. Well, Negritude is the whole complex of civilized values - cultural, economic, social and political - which characterize the black peoples, or, more precisely, the Negro-African world' (Senghor 1961: 6). These are the relational qualities that he describes as informed by intuitive reason' (Senghor 1961: 6). Citing the words of Cheikh Anta Diop,

'The historical circumstances which attended its birth seem fully to justify it. Nevertheless, we must draw attention to the fact that its content has been enriched with the passing of time, and has been renewed as circumstances have altered.' [Senghor notes that] Like life, the concept of Negritude has become historical and dialectical. It has evolved (Senghor 1961: 6).

If we are to think across historical moments and account for the thinking work that was 'before its time', it might help to contemplate how 'thinking itself must be recognized as an untimely operation situated at the intersection of the actual and imagined, the possible and impossible, the immanent and transcendent, the remembered and the anticipated' (Wilder 2015: 259). For example, Senghor depicts the psychologically troubling character/ nature of racism that is difficult to pinpoint 'rationally' and he does so by expanding the notion of reason to encompass things that are felt. Observing these negotiations can help orient us towards the sorts of moves thinkers make alongside the dominant ideas of their time, and towards the claims to lived experience of these enframing ideas. But, I want to interject a different story, one that presents lived experience against epistemic totalitarianism from another angle - bell hooks' experience of reading past patriarchy for liberation. In an essay that is subtitled 'What's love got to do with it?', hooks examines a process of coming to engage with loved ones who engage in violence and exploitation and who embody ideological frames that work to situate people in specific relation to authority (hooks 1996).

Although she does not use the word surreptitious, hooks' reading is useful for thinking about how to centre a humanistic caring that does not foreclose dialogue. She presents a story about being put on a feminist panel at a conference on Frantz Fanon that was meant to critique the patriarchy in his work. She takes several clever turns in this essay, but the most relevant for our discussion here is the way she discusses the development of her own literacies. She relates that it was growing up scared of her father that helped her develop the capacity to 'duck and roll' in the face of patriarchal blockades. Her skill and success at navigating patriarchal relations led her to read Fanon for his liberating ideas instead of feeling blocked by his reproduction of those kinds of relations. She tells us that 
she learned instead to see Fanon and her father as people in pain, as people also subject to the alienating power of patriarchal imperialist relations. This acknowledgement allows her to recognise not only their limitations, but also the kinds of interpersonal relations in which she developed literacy as a child, i.e. the kinds of relational practices within which she was socialised. This story gets at how lived experience conditions responses to epistemic closures. Rather than inviting us to avoid critical engagement, hooks encourages us to see how surreptitiousness - coming out of experiential literacies of power and connected to love of fellow beings - can yield a space for thinking and being free. I posit that Senghor achieves a similar orientation, in particular as regards his reimagining of the idea of culture.

\section{Reimagining culture}

Despite the historical specificities that attend to the 'birth' of Negritude, the audience is told that it did not remain stagnant. Rather, if we think of culture as transformative practice, we might hear that according to the anthropologists, no scientific basis for racial categories exists, that what appears as 'race' will eventually disappear through miscegenation. Senghor does note that he and his cohort realised that black culture (even as subordinated) will eventually disappear. He says that they wondered: what would be left for Negritude as a political platform? If the goal is dialogue, to find 'Africans' on the global map as interlocutors, I look to James Ferguson (2006) for the sad news that this remains largely unrealised. Given the black students' reading of European culture as 'discursive reason, technical skill, and a trading economy' (Senghor 1961: 6), they saw their efforts as contributing to the 'mainstream of cultural miscegenation' (Senghor 1961: 8) and preventing the transformation of European culture as hegemonic culture. Nevertheless, Senghor's speech turns towards the importance of thinking differently about culture:

Biological miscegenation, then, takes places spontaneously, provoked by the very laws which govern Life, and in the face of all policies of Apartheid. It is a different matter in the realm of culture. Here, we remain wholly free to co-operate or not, to provoke or prevent the synthesis of cultures. This is an important point. For, as certain biologists point out, the psychological mutations brought about by education are incorporated in our genes, and are then transmitted by heredity. Hence the major rôle played by Culture. We Negro-Africans and you Europeans thus have a common interest in fostering our specifically native values, whilst remaining open to the values of the Others. Do we not agree, then, that Culture, far from rooting us in materially determining factors - geography, ethnology and history - is in the end a means of transcending them? (Senghor 1961: 8).

Senghor is starting to present the logic of a solution to the crisis of coloniality. He presents a conception of culture as developed in-the-doing, or culture as a way to extri- 
cate people and communities from the tentacles of coloniality. We might read generously Senghor's comments on Black culture and European culture as stark because they are reflections of and constituted by a stark colonial system rather than as stagnant categories with very distinct characteristics. Insofar as he locates them within a logic of culture inthe-doing, he is not alone. For example, Busia, writing in 1962, develops a similar critique of a fixed idea of culture:

[C]ultures are not static. There is no society so custom-bound that its culture does not change, and there is none so changeful as to have no cake of custom. African cultures are not tied to a golden age in which there can be found, pure and complete, a priceless heritage that has been overlaid by an irreverent scientific age. It is not a question of peering into the past to rediscover the glory that was Africa. Such a conception of Africa fails to take account of the fact that every culture is - at every time - in the process of change. The cultures of African peoples have been growing continuously; they do have their roots in the past, but they stretch into the present, into the happenings of today, and of tomorrow (Busia 1962: 38).

In other words, culture must be understood as always already changing and carries within it the past, present, and the future. We might say also that education and knowledge are passed on to yield new practices of subjectification, such as that which incorporates European and Black African as a Self rather than as an Other. This is a logic that constitutes space for movement. If people embody culture and cultures manifest differently, and the context is one that supports dehumanising hierarchical relations, then a conception of culture as developing along with narrating ordinary human-ness offers language for thinking and speaking differently about humanity and universality. If culture is developed in-the-doing, it makes sense to understand culture as integral to social groups more generally.

At this point in Senghor's re-narrativising of a response to colonialism in an imperial centre, he introduces his idea of 'Civilisation of the Universal. With this framework, Senghor targets provincial conceptions of culture:

[W]e still disagree with Europe: not with its values any longer, with the exception of Capitalism, but with its theory of the Civilisation of the Universal, as formulated by the Society for European Culture... In the eyes of the Europeans, the 'exotic civilisations' are static in character, being content to live by means of archetypal images, which they repeat indefinitely.

Seen within this prospect of the Civilization of the Universal, the colonial policies of Great Britain and France have proved successful complements to each other, and black Africa has benefited. The policies of the former tended to reinforce the traditional native civiliza- 
tion. As for France's policy, although we have often reviled it in the past, it too ended with a credit balance, through forcing us actively to assimilate European civilization. This fertilized our sense of $\mathrm{Ne}$ gritude. Today, our Negritude no longer expresses itself as opposition to European values, but as a complement to them. Henceforth, its militants will be concerned, as I have often said, not to be assimilated, but to assimilate. They will use European values to arouse the slumbering values of Negritude, which they will bring as their contributions to the Civilization of the Universal (Senghor 1961: 8).

Thus, Negritude can be understood to be Africa's contribution to the human collective. Senghor claims that it is humanistic, complementary and evolving, which must be understood as an indispensible precondition for dialogue. 'The most serious criticism [of Europe] is that they have no idea of the preeminent dignity of the human person' (Senghor 1961: 8). In fact, the very distinction between civilised cultures and uncivilised cultures cultivates dehumanising practices.

Wallerstein (2006) cites the mid-16th century discussion of the 'right to intervene' between Las Casas and Sepulveda as one origin of this distinction between cultures capable of progress and those not capable of progress. He suggests that the distinction between Western civilisation and 'other' civilisations was the 'crucial defect... that made them [appear to be] incapable of proceeding to "modernity" (Wallerstein 2006: 75). This defect was defined as a 'cultural malady' that put in the service of dominance the idea of two kinds of culture, one which progressed and one which stagnated (Wallerstein 2006: 75). This distinction yields a response to power that reifies culture in attempts to show that difference is not necessarily unequal. Senghor's distinctive approach, however, is to note that some traditions dichotomise knowledge practices and others do not. He points out that the traditions that have not bifurcated ways of knowing are in a stronger position vis- $\grave{a}$-vis the dignity of the human person.

At stake here is the kind of fruitful, but contorted reading that relies on stretching the orientation of the reader. I say 'contorted' because, as bell hooks illustrates, sliding around the blockades that commonsense produces requires a kind of limberness. Wilder (2015: 8) critiques such a commonsense blockade that reads Negritude as a cultural phenomenon when he says that 'Negritude, whether embraced or criticized, was treated as an affirmative theory of Africanity rather than a critical theory of modernity'. If we listen to Senghor, we can hear the surreptitious critical theory of modernity that challenges its very organising principles that designate variations of human-ness. In his speech, he attacks as ludicrous the idea that Black African society is too 'stagnant' or 'primitive' to have guiding myths - or myths that act as guiding principles for society. Indeed, 'what are Free Enterprise, Democracy, Communism but myths around which hundreds of millions of men and women organize their lives? Negritude itself is a myth ... but a living dynamic one which evolves with its circumstances into a form of humanism' (Senghor 1961: 10). In contrast, European civilisation is not humanistic; rather it comes to appear anti-humanistic given its use of force in colonial domination and control. Senghor posits, 
Actually, our criticism of the thesis advanced by the Society for European Culture is that it is monstrously anti-humanist. For if European civilization were to be imposed, unmodified, on all Peoples and Continents, it could only be by force. That is its first disadvantage. A more serious one is that it would not be humanistic, for it would cut itself off from the complementary values of the greater part of humanity. As I have said elsewhere, it would be a universal civilization; it would not be the Civilization of the Universal.

Whereas our revised Negritude is humanistic. I repeat, it welcomes the complementary values of Europe and the white men, and indeed, of all other races and continents. But it welcomes them in order to fertilize and re-invigorate its own values, which it then offers for the construction of a civilization which shall embrace all Mankind. The Neo-Humanism of the twentieth century stands at the point where the paths of all Nations, Races, and Continents cross, where the Four Winds of the Spirit blow (Senghor 1961: 10).

On the face of it, these sentiments may appear idealistic. Yet, these statements made at one of the academic centres of the British Commonwealth are not neutral. They are part of a political platform of occupying that space and of maintaining allies, while pushing against powerful frames of recognition that designate the civilised and the brutish. In presenting an intelligible narrative of Negritude, and as one who was present at its birth, Senghor grabs hold of that narrative and wields it at other stories about how Negritude is understood and how a future audience might engage it. With his explanation of how $\mathrm{Ne}$ gritude developed, Senghor sidesteps the distinction between theory and practice and in effect grounds the development of theory in experience and productive practices. And, in doing this at Oxford, in particular, he highlights distinctions between British and French colonial practices that he surreptitiously indicates are otherwise quite similar. His reading of British practices implicates Oxford as part of the colonial apparatus, which makes it possible to 'unthink entrenched assumptions about Negritude as a nativism... and the postwar period as the Cold War order that came to be' (Wilder 2015: 256). In this provincialising of Europe and its non-humanistic humanism, Senghor participates in a conversation about humanism that is more robust than I can attend to here (see Said 2004). I want to suggest, though, that Senghor's understanding of humanism and his approach to dialogue can best be made sense of using Edward Said's defence of his own ideas regarding humanism against readings of it as a cultural phenomenon.

\section{Imagining a universal humanism}

James Clifford's well known critique dismisses Said's (1978) Orientalism as sweeping, as 'too broadly and abstractly pitched [and]... as overly systematic' (Clifford 1980: 206) and as not critical enough of liberal humanism, a theory at odds with Foucault's thinking, on 
which Said relies (Clifford 1980: 212). Clifford states that 'Orientalism is one of the first attempts to use Foucault systematically in an extended cultural analysis', which makes it a text of critical importance despite a number of troubling inconsistencies and ambiguities (Clifford 1980: 212). Said (2004) accepts Clifford's critique, but nimbly makes sense of it in this way:

Clifford correctly saw that I somehow remained unaffected by [French theory's] ideological antihumanism, mainly, I think, because I did not (and still do not) see in humanism only the kind of totalizing and essentializing trends that Clifford identified... [Further,] I believed then, and still believe, that it is possible to be critical of humanism in the name of humanism and that, schooled in its abuses by the experience of Eurocentrism and empire, one could fashion a different kind of humanism ... in ways that absorbed the great lessons of the past... (10-11).

By my reading, Senghor develops an argument closer to Said's much more recent comments that a non-totalising and non-essentialist humanism remains both necessary and possible. At this point in the speech, his analysis of humanism yields to a recognition that humanistic conditions cannot be achieved under conditions of exploitation. Therefore, while socialism is not necessarily humanistic, Senghor aims to think it so with an African inflection.

The African Mode of Socialism: The second part of this speech concentrates on how socialism is necessary for achieving a Negritudian form of humanism. In effect, there can be no recognition of a universal human-ness within a capitalist economic system, because it operates with a notion of progress that is premised on relations of exploitation that require modes of dehumanisation and alienation. Senghor says, 'Today [capitalism] is an out-of-date social and economic system - like Federalism, like Colonization... There can be no concrete freedoms - political, cultural, or spiritual - without economic freedom, [which cannot be understood as] the freedom granted to a minority to exploit the majority' (Senghor 1961: 10). Senghor presents the news that,

[A]mong the values of Europe, we had no intention, we still have no intention, of retaining Capitalism, not in its nineteenth-century form at least. Of course, private Capitalism was, in its early days, one of the factors of progress, just as Feudalism was in its time, and even Colonization. For the backwardness of black Africa, for example, has been caused less by colonization than by the Slave Trade, which in three centuries carried off some two hundred million victims, black hosts. Capitalism, then, thanks to the accumulation of financial resources and its development of the means of production, was a factor of progress (Senghor 1961: 10). 
I want to note here that Senghor reverses my claim above that capitalist progress is exploitative. Here, he cites capitalism as an emerging out of an exploitative idea of progress. Thus oriented, we are encouraged to centre our politics on people who created and are constituted by systems like capitalism. Instead of anti-capitalist politics (for anti-capitalism is not necessarily humanistic), we might rather push humanistic politics - a kind of interlocutory politics recognising that it would require a corresponding anti-capitalist stance.

His humanistic politics plus conditions on the ground - such as the role of faith and spirituality - made it necessary for Senghor to address Marx's treatment of religion in his thinking, in particular in his rethinking of Marx's analysis of capitalist exploitation. ${ }^{8}$ In this endeavour he is aided by Teilhard de Chardin's Neo-humanism, which holds that there is space in socialism for questions of faith and spirituality:

Upset with the Church rather than atheist, socialist but profoundly spiritual, an engaged militant in the defence and illustration of African values and more than ever in the search for the self, Senghor needed a general cosmology that would allow him to think about God, about different cultures in their equivalence, dialogue and convergence at the 'meeting place of give and take (Césaire's expression), and about socialism together (Diagne 2011: 157).

Diagne discusses how Senghor built on Chardin's rethinking of Marx and spirituality in a chapter aptly titled, 'Convergence' (Diagne 2011). In short, a civilisation of the universal or a universal humanism has to include Africans, who Senghor says have not embodied the Cartesian divide - the European Reason - that Senghor encompasses in his controversial reading of African Emotion, which I have discussed in detail elsewhere (el-Malik 2015). But the exploitative economic relations inhibit the possibility of a universal humanism, insofar as they are predicated on dehumanising practices that generate workers, profits, and progress. Marx's critique of this process is then indispensible for its analysis of precisely these practices, even though Marx cites religion as only numbing.

Senghor has set his sights on the idea that people produce the world, even people who are not designated as productive in a dominant world order. And he suggests, then, that in light of his 'excessively apocalyptic' vision, Marx lost sight of people's capacity to make decisions (Senghor 1961: 19). Senghor needs to present a space of decision-making, not just to aid analysis of African agency, but to carve out a space for the humanist understanding that he is trying to cultivate: that people make sense of their world and all are constrained by the onto-epistemological practices that coloniality wields. The argument could be made, and Senghor does make it in the speech, that coloniality's onto-epistemological practices impoverish everyone. Humanistic human-ness cannot be achieved within capitalist economic relations, or what Blaney and Inayatullah (2010) call 'savage economics'; 9 or, it is within a civilisation of the universal where the temporal walls of capitalism and progress can be dismantled; it is from a place of recognising people's humanity that interlocutory dialogue can begin to transcend the delimiting and violent kinds of relations that have come before it. 
Here, colonialist imperialism represents a mode of capitalism. Decolonisation, as it manifested, can be understood also as a mode of capitalism, rather than a break from colonialism. In the decolonial period, colonial flows of capital and resources continued 'after' colonialism, which 'goes some way to nullify the effects of the New Deal for underdeveloped countries: the European and American policy of 'gifts' (Senghor 1961: 12). In other words, flows of capital and resources were not troubled or effectively redirected after colonialism:

It is because private Capitalism finds it repugnant - or, more precisely, finds it impossible - to transcend its material bounds, it is because of its transformation into colonialist Imperialism, that we were converted, after much hesitation, to Socialism. As a matter of fact the general reasons I have just exposed were reinforced by more specific reasons arising from our colonial situation. It is undeniable that the principal motive of European overseas expansion was financial profit. I am not saying it was the sole motive. Trade opened the way to soldiers, missionaries, administrators. Private Capitalism's aim has always been to sell the products of European industry to native populations, at the highest price possible and to buy from them, at the lowest possible price, their raw materials. This is still the situation after the granting of independence... (Senghor 1961: 12).

Senghor tells his 1961 audience that formal independence did not lead to the end of coloniality. Given this, he sets the stage for a discussion of neo-colonialism and the necessity of socialist practice, but 'our socialism is not that of Europe' (Senghor 1961: 12). While socialism appears desirable for its humanistic qualities, it does not challenge domination and oppression. Instead, European socialism is based on Marx's thinking which, according to Senghor, did not deal with colonial exploitation based on race (Senghor 1961: 14). Senghor and his cohort grafted certain aspects of socialism onto Negritude, and claimed that it is traditionally socialist in ethos, but they were clear, this not the socialism that is a response to only divisions of economic inequality. Colonial conditions require a different approach to human well-being, a different starting point than that of European socialism. Thus, it can be said that socialism, like any political economic system, must be grounded in specific and localised practice or that 'socialism "in general" does not exist unless it is incarnated, inculturated' (Diagne 2011: 182).

\section{Imagining a humanistic future}

Senghor builds on the earlier section of his speech that develops the idea of a universal humanism, which is both a necessary precursor to and a powerful outcome of economic democracy and spiritual freedom, when he says that,

Mr. Potekhin, the Director of the African Institute in Moscow, in his book entitled Africa Looks Ahead, gives the following definitions of 
'the fundamental traits of the Socialist society. The State's power is vested in the workers. All means of production are collective property, there are no exploiting classes, nor does one man exploit his fellow; the economy is planned, and its essential aim is to afford the maximum satisfaction of man's material and spiritual needs.' Obviously, we cannot withhold our support from this ideal society, this earthly paradise. But it still has to come about, the exploitation of man by his fellow has yet to be stamped out in reality, the satisfaction of the spiritual needs which transcend our material needs has to be achieved. This has not yet happened in any European or American form of civilization: neither in the West nor the East. For this reason we are forced to seek our own original mode, a Negro-African mode, of attaining these objectives, paying special attention to the two elements I have just stressed: economic democracy and spiritual freedom (Senghor 1961: 12).

In this case, national independence is an argument produced by and within the process of decolonisation, but other arguments also emerged. This speech at Oxford is a reminder 'to [avoid] mistak[ing] a product of decolonization for an optic through which to study it' (Wilder 2015: 4). National independence is one outcome of the decolonisation moment. The optic might include the narratives of political struggles out of which the idea of national independence came to loom large. Senghor's speech, written and delivered at a time before this narrative came to dominate the conversation but perhaps after one might have suspected this outcome, helps us to read this imaginative engagement in another way. Listen to this:

Marx nowhere deals with this form of inequality, this domination, and the struggle for freedom which they were to provoke. That was one of his omissions, which we had to repair by starting from our own situation, extrapolating, nevertheless, from his analyses and his theory, pressing them home to the very last of their logical implications... In hard fact, as we must have the clear sight - and the courage - to admit, the rise in the standard of living of the European worker has been effected, through a colonial slave economy, to the detriment of the masses in Asia and Africa. Hence, the difficulties of decolonization. I do not seek to deny, in this process of decolonization, the disinterested action of certain noble minds, of intellectuals spurred on by a high ideal of brotherhood. These men and women have saved Europe's honour, and made possible the co-operation between Africa and Europe which exists today. But I would say that they were not in the majority, that decolonization, as General de Gaulle admits in his plain-speaking magnanimity, now suits the needs of Europe and the conditions imposed by the Cold War (Senghor 1961: 14-16). 
This imagining of other potential futures that did not come to pass is precisely the contribution that Wilder posits Senghor (and Césaire) offers us. He says, they identified within an already superseded empire the elements of an unprecedented federal democracy' (Wilder 2015: 259). If this is so, and Senghor's Oxford Speech, among other writing, supports the claim, then '[Cesaire and] Senghor's visions of self-determination without state sovereignty, legacies that they inherited and willed, should surely count as a fecund source for an effective history of our present through which to glimpse a possible future' (Wilder 2015). To put it another way, if thinkers of the decolonisation moment imagined a future that did not come to be our future, then we should consider those possible futures as part of our histories and let them influence how we imagine a future not yet passed.

If we take Senghor at his word, the main task before his Oxford audience is to use decolonisation to reconfigure the relationship between Europe and Africa with people at the centre. He conceives of this task as a practical one; the exact nature of the current position (materially, politically, socially) must be studied. He is developing the argument for communal well-being that he rehearses elsewhere (Senghor 1964; 1965), but here he discusses the need for knowledge of actual conditions,

[W]e must first make a survey of our riches, our potentialities and our shortcomings: not only our material riches, potentialities and shortcomings, but also technical and human ones. The Plan for Social and Economic Development is then drawn up on the basis of this survey. This is a working hypothesis; it is, above all, the harmonious organization of financial and technical inter-relationships, and even cultural and social ones, all of which have as their primary objective, I repeat, the satisfaction of material needs: housing, food clothing, transport, etc. ... At this level, co-operation is the positive aspect of syndicalism. Here it is not only a matter of suppressing private Capitalism, it is a question of replacing it, by organizing work on a collective basis for the benefit of the workers. The workers in field and factory must take over the means of production and organise them more rationally. That is, more efficiently, thanks to help from the State, and the new hope aroused in them by their re-won freedom, of which they now have a living experience (Senghor 1961: 16 , emphasis in original).

If we listen closely to what he does, we might note that Senghor returns to lived experience, the necessity of people at the centre of these politics and the importance of attending to practical tasks. We can then hear, perhaps, that this is the moment when Senghor's dance with Oxford reaches a crescendo. His acceptance of the contingencies of the midtwentieth century means that he must navigate those contingencies. Therefore,

[W]e have not legally suppressed private Capitalism, which is foreign to our country; we have not... nationalized anything. Above all, we have not shed a single drop of blood. Why? Because we began by 
analysing our situation as an underdeveloped and colonized country. The essential task was to win back our national independence. Next we had to eliminate the flaws of colonial rule while preserving its positive contributions, such as the economic and technical infrastructure and the French education system. Finally, these positive contributions had to be rooted in Negritude, and fertilized at the same time by the Socialist spirit to make them bear fruit (Senghor 1961: 16, emphasis added).

I say crescendo because, in the end, Senghor accepts national independence, which he does not equate with self-determination; he continues to evaluate how to achieve humanistic social relations; and at Oxford, he cites as one of the two most useful contributions of colonialism: the French education system. Together with Negritude and an African-inflected Socialism, economic and technical infrastructure and the French education system have the potential to yield a civilisation of the universal in which all people can be seen as potential interlocutors!

To summarise what Senghor tells his Oxford audience about African Socialism until this point, he first analyses Senegal's situation as an underdeveloped and colonised country. Second, he eliminates the flaws of the colonial system, but keeps positive contributions. Third, he roots the positive contributions in an enriched Negritude. And fourth, he incorporates capital into a development plan. But, insofar as the very humane-ness of humanity is at stake, Senghor now turns to deprovincialising the idea of Man:

In this new world-view, historical and dialectical materialism remains fertile, to the extent that we extract all its consequences. But Matter, 'Holy Matter', is no longer the indefinable thing it used to be. On analysis, it appears, through a bold reversal in the dialectical process, to be subtended by a radial energy, of a psychic nature. And this, paradoxically, is what it has always been in Negro-African ontology. History is no longer restricted to Man nor to the West; it plunges, way back beyond Pre-History, into Geology.

In this retrospective-prospective vision, in this total History, which is founded on Evolution, Man loses his position of domination, only to rediscover it on the farthest edge of the biological and cosmic drift, equipped with its irreducible idiosyncrasies. His essential idiosyncrasy is the tendency for all peoples, nations and races to merge, whereas other living beings are differentiated and dispersed through the development of species.

Now, seen from this view, the class struggle, the corner stone of Marxist theory, is set in its true place. It becomes simply one aspect among many of the conflict which sets social groups, nations and continents 
one against the other. In Europe - and in America - classes are being transformed into technico-professional groups, and the conflict between them is gradually resolved in balanced syntheses, following the human tendency to merge. It has already been pointed out that the American and Soviet social systems are growing more like each other, even though they are enemies (Senghor 1961: 18).

The class struggle is just one struggle among others; social groups have conflicts, myth and culture. This is a somewhat banal reading of humanity. But it tells us that in the end, like bell hooks, Senghor believes in love.

\section{Reading imaginative futures with Senghor}

The decolonisation moment of the mid-twentieth century represents what I have called a 'crevice moment', a moment of disruption in hegemonic forms of discursive consolidation (el-Malik 2013). Political struggles against colonialism developed new intelligibilities after World War I as a result of both 'an epistemological shift in social and human sciences' (Mudimbe 1992: 436) that upset commonplace conceptions of civilized and primitive and the emergence of a 'new African text' that responds to 'Christian and colonial paradigms' (Mudimbe 1992: 437). These new discussions are reflected in Senghor's speech. The interwar period is marked by what Genova (2004: 274) calls 'évolué class consciousness [which was] organized around assertions of their unique position within the colonial field, astride the divide between French and African cultures, between citizen and subject'. In other words, the French-educated colonial diasporic intellectual collective of which Senghor was a member came to occupy an in-between political position: not quite civilised/not quite French. Their very presence upset the categorical divisions that stabilised colonial relations, but contemporaneous geo-politics offered opportunities for thinking differently. Senghor continues,

For now the great conflicts of History take place between nations we call them the Cold War and Decolonization. [The Westphalian world order makes these conflicts appear this way.] They are only the exterior signs of the painful labour, from which will be born the world of the Future, with all divisions healed (Senghor 1961: 18).

Why and how? Or, for whom and by whom? Now we come to the problem of ultimate goals and methods, of ends and values. This is an aspect which Marx, in his excessively apocalyptic and deterministic vision, failed to stress sufficiently, forgetting that, as he progressed, Man remained free to choose; he could accept or reject progress, depending on whether he found the goal attractive or not (Senghor 1961: 19).

Senghor read Marx as more pessimistic than conditions required, which he associated with Marx's own sense of people's capacities. Acknowledging the sophistication of Marx's 
sociology, Senghor (1964: 27-38) suggests that his pessimism rests not in his observations regarding capitalism, but in his own Christianity-inflected lack of faith in humanity. Senghor seems to think that there is room to move, that there is room for politics, and this speech illustrates how moves can be made even in tight spaces. Arguably, though, the critical moment of possibility emerged in the 1940s, when spaces for movement expanded. As Cooper (2014: 7) notes:

WWII created an opening in French politics that Africans were able to pry wider. France's defeat at the hands of Germany in 1940, the installation of a collaborationist regime in France itself, its loss of effective control over Indochina to the Japanese, and the destruction of the war left French politicians with the task of reinventing their country.

The post-war moment and the shock of seeing colonial violence in Europe yielded a moment when complex and imaginative kinds of thinking were possible and intelligible to proportionally greater numbers of people than earlier in the century. Certainly this was the case even amongst those early proponents of Negritude, who Senghor narrates as having moved away from racialism after seeing the Third Reich's camps liberated. He has faith in the possibilities afforded by this crevice moment, as we see with his last words here at Oxford.

Conclusion: Senghor ends this speech with the notion that African socialism is premised on a Negritudian humanism and aspires to a generally fuller being that is Africa's contribution to the Civilisation of the Universal:

From now on, our duty as Negro-Africans is plain. We remain free to travel with the current, or to row against it. I say 'our duty'. I should say 'our easily appreciable interests', which lie in the direction of the Civilization of the Universal, of a Socialism revised as Socialization, in which body and soul shall be fulfilled, and know the ineffable rapture of Love-in-Union. That Civilization of the Universal, to which we shall contribute, when all is said and done, by pouring into it the burning lava of our Negritude, those values of our civilization which I have defined above. If we were missing, Civilization would lack the rhythm section of its orchestra, the bass voices of its chair. Henceforth, revised Socialism will have as its counterpart revised Negritude, which, let me repeat, is a form of Humanism.

Such are the thoughts, (far too long, I know), that the University of Oxford inspires in me. Black Africa and the whole world are deeply in its debt. Oxford is one of the peaks of the Civilization of the Universal (Senghor 1961: 22).

The speech is over. I can imagine the collective exhalation, and (perhaps polite) clapping. Senghor's speech releases into the room a decolonial future that might have been 
possible in the aftermath of WWII. It is a vision of a decolonial future that 'begin [s] with empire as our unit of analysis [British and French, in this case], which [weakens] the case for insisting on cultural... or epistemological singularity', and yet keeps alive the idea and the hope of a more universal universalism that could yield dialogue (Wilder 2015: 10). Senghor is quite consistent in his position that 'we are all in this together' in what Diagne (2011: 143) calls, a philosophy of dialogue and convergence', or a deep mixing. This orientation is apparent in the way Senghor heralds Oxford University as a beacon of knowledge production, normalises its contribution to colonial relations, and makes ordinary his own presence in its halls.

Wilder says that 'Senghor's postwar work invites us to deterritorialize social thought and to decolonize intellectual history' (Wilder 2015: 11). Studying how power works, how hegemonic practices of making sense shut out other kinds of practices that might make a different kind of sense, exposes how important this invitation still is. It is still crucial to consider what specific inheritances in specific moments and places can teach us about what it means to be human. This 'I' wonders whether it is possible to imagine 'this moment' as a crevice moment and whether Senghor's strategy of speaking 'on the record' ideas that may be ahead of their time to keep their political potential alive is a strategy that can be fruitful. If this moment is a crevice moment or if it is possible to read across historical moments, then it might be possible to narrate how dehumanising practices can yield terrible consequences. It might be possible to nourish the idea that it is important to recognise people as interlocutors in our reading through to the present. It might be possible to protect (perhaps in the archives, for I found this speech in archives) storylines that imagine kinder futures. One might say that '[i]dentifying and fashioning "historical constellations" is one way of writing a "history of the present" (Wilder 2015: 33). Historical constellations might put in conversation speakers across common sense blockades, such as I have tried to do here. The fashioning of constellations requires the flexibleness that bell hooks encourages, a kind of nimbleness that emerges from the experience of engaging relations of power without dehumanising ourselves or our potential interlocutors. A focus on the surreptitious can aid in the work of configuring constellations of reading alongside, thinking with, and arguing for.

\section{Notes}

1 This skill is credited to his having fielded a teacher's insults after which '[Senghor] made an early resolve always to have logic, evidence, and research to back up the graceful words that came to easily to him as a poet and writer' (Vaillant 1990: 164).

2 Trouillot (1995: 82) writes that 'the unthinkable is that which one cannot conceive within the range of possible alternatives...' making it also a historically contingent process such that unthinkability can only be theorised within specificities.

3 Britain recognised difference institutionally through indirect rule and education policy. See Sharkey (2003) for a rich analysis of how indirect rule worked in Sudan through the establishment of Gordon College.

$4 \quad$ Sharpley-Whiting's (2002) Negritude Women expands the analysis of bright young women and men who found themselves positioned as outsiders to a France of which they imagined themselves to be a part. 
6 Markovitz (1969: 51) points out that Senghor did not say 'put yourself in my place', but instead said, 'assume a black skin'. Markovitz reads Senghor as making a distinction between his existential position and the superficiality of his black skin and how it is made sense of in that historical moment.

$7 \quad$ It is worth noting here that Negritude was only one response to the experience of French colonialism. Richardson (1996: 8-16) presents a helpful discussion of Menil parting ways with Cesaire on the point of Negritude. The point here is that while Negritude (as with any political response to power) was contested, it was both an emotional response to lived conditions and a thoughtful, evolving, and engaged politics that had to navigate challenging questions, like the extent to which its proponents perpetuated and reinforced the power of essentialising and oppressive categories, such as race.

8 Senghor (1964) writes what remains the most accessible synthesis of Marx that I have ever read. He applies 'to Marx, the Marxian method, the historical method' (Senghor 1964: 37) and illustrates a rich contribution without reifying the man himself.

9 Senghor's arguments here can be extended with Blaney and Inayatullah's Savage Economics (2010), which links the ideas in this speech with their excellent, current, and critical analysis of the discipline of international political economy.

\section{References}

Busia, Kofi Abrefa. 1962. The Challenge of Africa. New York: Praeger Publisher.

Clifford, James. 1980. 'Review essay: Orientalism', History and Theory 19(2): 204-223.

Cooper, Frederick. 2014. Citizenship between Empire and Nation: Remaking France and French Africa, 1945-1960. Princeton and Oxford: Princeton University Press.

Diagne, Souleymane Bachir. 2011. African Art as Philosophy: Senghor, Bergson, and the idea of Negritude. London: Seagull Books.

el-Malik, Shiera. 2015. 'Interruptive Discourses: Léopold Senghor, African Emotion and the poetry of politics', African Identities 12(3): 49-61.

. 2013. 'Intellectual Work “In-the-World”: Women's Writing and Anti-colonial Thought in Africa', Irish Studies in International Affairs 24: 101-120.

Ferguson, James. 2006. Global Shadows: Africa in the Neoliberal World Order. Durham: Duke University Press.

Genova, James E. 2004. Colonial Ambivalence, Cultural Authenticity, and the Limitations of Mimicry in French-Ruled West Africa, 1914-1956. New York: Peter Lang.

hooks, bell. 1996. 'Feminism as a Persistent Critique of History: What's love got to do with it?' In Alan Read (ed), The Fact of Blackness: Frantz Fanon and Visual Representation. Seattle: Bay Press. pp. 76-85.

Mudimbe, Valentin-Yves (ed). 1992. The Surreptitious Speech: Présence Africaine and the Politics of Otherness 1947-1987. Chicago: University of Chicago Press.

Michael Richardson (eds). 1996. Refusal of the Shadow: Surrealism and the Caribbean. Translated by Krzysztof Fijalkowski. New York: Verso.

Said, Edward. 2004. Humanism and Democratic Humanism. New York: Columbia University Press.

Senghor, Leopold Sedar. 1964. On African Socialism. London: Praeger. Originally published by Présence Africaine in 1961.

1961. Lecture Given by H.E. the President of the Republic of Senegal at St. Anthony's College, Oxford University, 26th October, 1961. pp. 1-11. 
Sharkey, Heather Jane. 2003. Living with Colonialism: Nationalism and culture in the Anglo-Egyptian Sudan. Berkeley: University of California Press.

Sharpley-Whiting, Tracey. 2002. Negritude Women. Minneapolis: University of Minnesota Press.

Trouillot, Michel-Rolph. 1995. Silencing the Past: Power and the production of history. Boston: Beacon Press.

Wallerstein, Immanuel. 2006. European Universalism: The Rhetoric of Power. New York: The New Press. Wilder, Gary. 2015. Freedom Time: Negritude, Decolonization and the Future of the World. Durham: Duke University Press.

\section{Acknowledgements}

I thank Naren Kumarakulasingam for his gentle editorial assistance and patience, and kind readings. I am grateful to two Contexto reviewers who generously returned rich feedback on a very rough draft of this experimental article. I was lucky enough to be able to present a late version of this paper at the Minnesota International Relations Colloquium, at which I received more incredibly helpful feedback than I was able to include at this time, but have saved for another time! Special thanks go to Maria Mendez Gutierrez, Garrett Johnson and everyone there. Lastly, I thank Jacob Stump, Isaac Kamola, Sam Opondo for reading versions of this article and for talking with me about the ideas in its pages.

\section{About the author}

Shiera S. el-Malik is an associate professor in the Department of International Studies at DePaul University in Chicago, USA. She teaches and writes on themes of coloniality, politics, and theory. Her research is guided by an interest in the intersection of politics of knowledge and lived experience. Her work has been published in the Review of International Studies, African Identities, Journal of Contemporary African Studies, Irish Studies of International Affairs, Critical Studies on Security, African and Black Diaspora amongst other journals and edited volumes. Her co-edited (with Isaac Kamola) volume Politics of African Anticolonial Archive is forthcoming from Rowman and Littlefield Publishers.

Received on 9 April 2016, and approved for publication on 14 October 2016. 